\title{
FORMakademisk og forskningsbasert undervisning innen høyere utdanning i design og designdidaktikk
}

I Hernes-utvalgets rapport fra 1988 står det at "kjennetegnet på høyere utdanning er at den er forskningsbasert" (Universitets- og, høyskoleutvalget, \& Hernes 1988:89). Universitets- og høgskoleloven fastslår at høyere utdanning skal være forskningsbasert (Kunnskapsdepartementet 2005: §1-3). Denne loven sidestiller forskning og kunstnerisk utviklingsarbeid, blant annet fordi de to bygger på helt ulike dokumentasjonsformer. Dette betyr imidlertid ikke at undervisning innen kunstfag er fritatt for også å være forskningsbasert.

At all undervisning ved universitet og høgskoler skal være forskningsbasert fremheves også i St.meld. nr. 30 (2008 - 2009) Klima for forskning:

Prinsippet om forskningsbasert undervisning handler ikke bare om å utdanne mennesker med kompetanse til å løse viktige oppgaver i samfunnet. Det handler i vel så stor grad om at kontakten med forskning skal utvikle studentenes evne til refleksjon, kreativitet og kritisk tenkning. Koblingen mellom forskning og undervisning er nok et eksempel på at kulturelle og instrumentelle begrunnelser henger sammen (Kunnskapsdepartementet 2009:10).

Kravet om forskningsbasert undervisning gjelder også høyere utdanning innen design og designdidaktikk, som er de primære forskningsfeltene som publiseres i tidsskriftet FORMakademisk. Som relativt unge forskningsfelt blir mye av forskningen innen design og designdidaktikk publisert som artikler heller enn monografier. Tidsskriftet spiller derfor en viktig rolle som kilde til forskningsbasert undervisning. FORMakademisk er også det eneste norske vitenskapelige tidsskriftet innen dette området.

Ved at FORMakademisk publiserer artikler på norsk, bidrar vi i tillegg til at universitet og høgskoler kan oppfylle kravet i Universitets- og høgskoleloven til "vedlikehold og videreutvikling av norsk fagspråk" (Kunnskapsdepartementet 2005:§1-7) innen design og designdidaktikk.

I FORMakademisk legger redaksjonen vekt på å bruke de mest kompetente fagfellene vi kan finne nasjonalt og internasjonalt for å vurdere artiklene før publisering. Det gjør vi for å utvikle en så høy standard som mulig på den forskningen vi publiserer. Dette krever mye arbeid, men er svært viktig for at det vi publiserer skal være relevant og ha god kvalitet for lærere og studenter i høgere utdanning innen design og designdidaktikk.

For at høyere utdanning innen design og designutdanning skal kunne ha nytte av denne viktige publiseringskanalen også i framtida er det avgjørende at institusjonene og organisasjonene innen design og designdidaktikk støtter tidsskriftet økonomisk.

I dette nummer av FORMakademisk skriver Judith Gloppen om en økende interesse blant forskere, praktikere og organisasjoner for hvordan design kan være nyttig innen ledelse, spesielt når dette skjer $\mathrm{i}$ en tjenestesammenheng. I denne utforskende kvalitative studien, undersøker hun et slikt tverrfaglig skjæringspunkt, med sikte på bedre å forstå hvordan tjenestedesign kan være verdifullt på et strategisk nivå for ledere i organisasjoner.

Nina Scott Frisch utforsker i sin artikkel hvordan vokabularet til kulturhistorikeren professor Ernst Gombrich kan benyttes i forhold til barns tegneprosesser (alder 9-12). Hans begreper er relatert til deres mulige teoretiske opprinnelse og plassert $\mathrm{i}$ en sosiokulturell forståelse av menneskelig aktivitet. De er videre kontrastert til andre relevante begreper i en tegneundervisningssammenheng.

Per Gunnar Røe og Inger-Lise Saglie skriver i sin artikkel at det allerede på 1970- 
tallet ble argumentert for at forstadsbyer i USA hadde utviklet seg til "minicities", som tilbyr et bredt spekter av muligheter for forbruk, kulturarrangementer og en følelse av det urbane. I denne artikkelen undersøker de i hvilken grad denne beskrivelsen av minicities kan være gyldig i to forstadsbyer i omlandet til Oslo, Asker og Sandvika. De diskuterer videre om "urbanisering" av disse forstadsbyene kan bidra til en mer bærekraftig byutvikling, med hensyn til daglige reiser.

Gudrun Helgadottir skriver at den islandske genseren presenteres og oppfattes som tradisjonell - til og med eldgammel - autentisk islandsk, og håndlaget av islandske kvinner av ull fra islandske sauer. Likevel, denne gensertypen, den såkalte "islender" eller "Icelandic sweater' på engelsk, dateres bare tilbake til midten av det 20. århundre og er ikke nødvendigvis laget på Island, heller ikke av islandsk ull. Likevel er genseren en vellykket oppfinnelse av en tradisjon, populær blant islendinger og turister siden introduksjonen i midten av det 20. århundre. Den har fått rollen som et nasjonalt symbol, spesielt i krisetider for eksempel ved gjenoppbyggingen av verdiene i kjølvannet av den islandske bankkrisen i 2008.

Erlend Vinje presenterer resultatene fra en spørreundersøkelse som ble gjennomført blant lærere i Oslo-skolen høsten 2010. Undersøkelsen tok sikte på å finne lærernes preferanser knyttet til skolearkitektur, samt å finne lærernes oppfattelse av relasjonene mellom skolearkitektur og mulighetene for utøvelse av viktige lærerkompetanser.

Karen Brcenne har skrevet en artikkel, med bakgrunn i nordisk historieforsking på skolefagene Kunst og handverk, Bild/Billedkunst og Slöjd (Sverige og Danmark). Hun drøfter hvordan to fagideologiske ståsteder, den kunstpedagogiske og den handverksfaglige tradisjonen, har blitt segmentert innen en norsk kunst- og designdidaktisk fagkontekst. Spørsmålet som blir diskutert er hvordan ulike sider ved formgivingsaktiviteten får verdi som ideologi hos fagaktører innen det kunst- og designdidaktiske feltet.

Oslo, desember 2011

Janne Beate Reitan

Ansvarlig redaktør

\section{Referanser}

Kunnskapsdepartementet (2005). Lov om universiteter og høyskoler from http://www.lovdata.no/all/hl20050401-015.html\#1-7.

Kunnskapsdepartementet (2009). Klima for forskning, St.meld.30 (2008-2009) Available from http://www.regjeringen.no/nb/dep/kd/dok/regpubl/stmeld/2008-2009/stmeld-nr-30-2008-2009-.html

Universitets- og, høyskoleutvalget, \& Hernes, Gudmund (1988). Med viten og vilje: innstilling fra Universitetsog høyskoleutvalget. Oslo: Statens forvaltningstjeneste. Informasjonsforvaltning. 